Yukinobu Anzai MD, Toshiaki Nishikawa MD, Akiyoshi Namiki MD

\title{
Attenuated sympa- thetic tone augments nitrous oxide-induced myocardial depression during high-dose fentanyl anaesthesia in dogs
}

The purpose of this study was to determine whether centrally mediated sympathetic tone exerts compensatory effects on nitrous oxide-induced myocardial depression during high-dose fentanyl anaesthesia. The cardiovascular responses to 60 minutes of nitrous oxide administration after fentanyl, 100 $\mu \mathrm{g} \cdot \mathrm{kg}^{-1}$, were examined in 18 dogs with or without autonomic blockade induced by hexamethonium. Decreases of cardiac output and left ventricular stroke work were significantly greater in dogs with autonomic blockade $(\mathrm{n}=9)$ by about 20 per cent of baseline values than in dogs without autonomic blockade $(\mathrm{n}=9)$ at 30, 45, and $60 \mathrm{~min}$. Similarly, left ventricular $d P / d t$ was reduced more in dogs with autonomic blockade than in dogs without autonomic blockade, but this difference was only significant at the 60-min period. It is concluded that the sympathetic nervous system provides partial compensation for myocardial depression induced by nitrous oxide in the presence of high-dose fentanyl, suggesting that large doses of fentanyl do not ablate the centrally mediated sympathomimetic effects of nitrous oxide.

Le but de cette étude était de déterminer si la réponse sympathique d'origine centrale amène une compensation sur la

\section{Key words}

ANAESTHETICS, GASES: nitrous oxide; ANAESTHETICS, INTRAVENOUS: fentanyl; SYMPATHETIC NERVOUS SYSTEM: ganglionic blockade transmission, hexamethonium.

From the Department of Anaesthesiology, Sapporo Medical College and Hospital, and the Department of Anesthesiology, Institute of Clinical Medicine, University of Tsukuba.

Address correspondence to: Dr. Y. Anzai, Department of Anesthesiology, Sapporo Medical College and Hospital, South-1, West-16, Chuoku, Sapporo 060, Japan. dépression myocardique induite par le protoxyde d'azote lors d'une anesthésie à haute dose de fentanyl. Les réponses cardiovasculaires après administration de 60 minutes de protoxyde d'azote après $100 \mu \mathrm{g} \cdot \mathrm{kg}^{-1}$ de fentanyl, ont été examinées chez 18 chiens avec ou sans blocage du système sympathique induit par l'hexamethonium. La diminution du débit cardiaque, du travail du ventricule gauche étaient significativement plus grands chez les chiens ayant eu un blocage du système autonome $(\mathrm{n}=9)$. Cette augmentation se chiffrait d 20 pour cent des valeurs de contrôle comparativement à celles des chiens qui n'ont pas eu de blocage du système autonome $(\mathbf{n}=9)$ d 30 , 45, et 60 minutes. Egalement le dP/dt du ventricule gauche était moindre chez les chiens ayant un blocage du système autonome comparativement aux chiens qui n' ont pas eu de blocage. Mais celte différence n'était significative qu'après 60 minutes. On conclut que le système nerveux sympathique amène une compensation partielle de la dépression myocardique induite par le protoxyde d'azote en présence de fortes doses de fentanyl suggérant que de larges doses de fentanyl n'abolissent pas la réponse sympathomimétique d'origine centrale produite par le protoxyde d'azote.

Nitrous oxide $\left(\mathrm{N}_{2} \mathrm{O}\right)$ has been known to produce significant myocardial depression when added during high-dose fentanyl anaesthesia. ${ }^{1-5}$ Several studies have reported a dual effect of $\mathrm{N}_{2} \mathrm{O}$ on cardiovascular dynamics: direct myocardial depression, ${ }^{6}$ and activation of the sympathetic nervous system. ${ }^{6,7}$ The sympathomimetic effect of $\mathrm{N}_{2} \mathrm{O}$ has been shown to depend on the basal volatile anaesthetic with which it is used. ${ }^{8-10}$ In the presence of opioids, however, there has been much debate whether sympathetic stimulation is associated with the use of $\mathrm{N}_{2} \mathrm{O} .^{1-4.11,12}$ It has been suggested that opioids block centrally mediated sympathomimetic effects of $\mathrm{N}_{2} \mathrm{O}$, thus unmasking its direct depressant effect on the heart. ${ }^{13,14}$ Therefore the 
present study was performed to evaluate the role of the sympathetic nervous system in compensating for $\mathrm{N}_{2} \mathrm{O}$. induced myocardial depression during high-dose fentanyl anaesthesia.

\section{Methods}

Experiments were performed on 18 adult mongrel dogs, ranging in weight from 8 to $15 \mathrm{~kg}$, which were cared for according to institutional guidelines for laboratory animals. The protocol was approved by the institutional animal investigation committee. All dogs were anaesthetized with $30 \mathrm{mg} \cdot \mathrm{kg}^{-1}$ pentobarbital and their tracheas were intubated. The lungs were mechanically ventilated to maintain normocapnia using a volume-cycled animal respirator (R-60, Aika, Tokyo) with 100 per cent oxygen. Additional doses of $5 \mathrm{mg} \cdot \mathrm{kg}^{-1}$ pentobarbital were administered when required to maintain anaesthesia during the surgical procedures. Sodium bicarbonate was given to maintain a normal buffer base. Oesophageal temperature was kept at $38 \pm 1^{\circ} \mathrm{C}$ with a warm water blanket.

Following placement of subcutaneous ECG electrodes, cannulae were inserted into the femoral artery and a peripheral vein for measurement of continuous systemic arterial pressure (SAP), arterial blood sampling, and administration of fluids and drugs. Lactated Ringer's solution was infused at a rate of $5 \mathrm{ml} \cdot \mathrm{kg}^{-1} \cdot \mathrm{min}^{-1}$ for the duration of the experiment. Heart rate (HR) was continuously recorded by a cardiotachometer. A thermodilution flow-directed balloon-tipped catheter (5Fr, American Edwards Laboratories) was introduced into the pulmonary artery via the external jugular vein for measurement of pulmonary artery pressure (PAP), central venous pressure (CVP), and cardiac output (CO). A transducertipped catheter (MPC-500, Miller) was implanted in the carotid artery through a small incision and threaded to the left ventricle to obtain the left ventricular end-diastolic pressure (LVEDP) and the instantaneous rate of rise of left ventricular pressure $(\mathrm{LV} \mathrm{dP} / \mathrm{dt})$.

Haemodynamic measurements included SAP, HR, PAP, CVP, LVEDP, LV dP/dt, and CO. All haemodynamic variables were recorded using a polygraph system (RM-6000, Nihon-Kohden, Tokyo). All pressures were measured at end-expiration by calibrated Statham P23ID transducers (Gould). Cardiac output was obtained at endinspiration by the thermodilution method in triplicate, using $3 \mathrm{ml}$ of iced five per cent dextrose in water and a $\mathrm{CO}$ computer (model 9520A, American Edwards Laboratories). Mean systemic and pulmonary artery pressures (MAP and MPAP) were calculated as diastolic pressure plus one-third of pulse pressure. Derived haemodynamic variables were systemic vascular resistance [SVR = (MAP-CVP) $\times 80 / \mathrm{CO}$, pulmonary vascular resistance $[$ PVR $=($ MPAP-LVEDP $) \times 80 / C O]$, left ventricular stroke work [LVSW $=($ MAP-LVEDP) $\times \mathrm{CO} \times 0.0136$ $\mathrm{HR}$, and right ventricular stroke work [RVSW = (MPAP-CVP) $\times \mathrm{CO} \times 0.0136 / \mathrm{HR}]$. Eighteen dogs were divided into two groups. Dogs in Group $1(n=9)$ received fentanyl, $100 \mu \mathrm{g} \cdot \mathrm{kg}^{-1}$, IV over five minutes. After a stable haemodynamic period was obtained, baseline measurements were performed. Thereafter the lungs were ventilated with 70 per cent $\mathrm{N}_{2} \mathrm{O}$ in oxygen for $60 \mathrm{~min}$, and then with 100 per cent oxygen for an additional $15 \mathrm{~min}$. Haemodynamic data were obtained at 15 min intervals over this 75-min period. Dogs in Group 2 $(n=9)$ initially received hexamethonium, $20 \mathrm{mg} \cdot \mathrm{kg}^{-1}$ IV. Decreased LVEDP was restored to the prehexamethonium level with $20-30 \mathrm{ml}$ of low molecular weight dextran. Loss or attenuation of the autonomic nervous activity was confirmed by testing the baroreflex responses (pressor test; phenylephrine $5 \mu \mathrm{g} \cdot \mathrm{kg}^{-1}$, depressor test; nitroglycerin $10 \mu \mathrm{g} \cdot \mathrm{kg}^{-1}$ ) before and $20 \mathrm{~min}$ after hexamethonium. Autonomic blockade was maintained with hexamethonium, $5 \mathrm{mg} \cdot \mathrm{kg}^{-1} \cdot \mathrm{hr}^{-1}$, IV throughout the experiment. The remaining procedures were identical to those in Group 1.

All data were expressed as mean \pm SD. Statistical analysis was performed by analysis of variance with repeated measures followed by Student's t test. $P<0.05$ was considered statistically significant.

\section{Results}

The two groups were similar in weight $(9.8 \mathrm{~kg} \pm 1.9 \mathrm{in}$ Group 1 vs $10.2 \mathrm{~kg} \pm 1.4$ in Group 2). The baroreflex responses were almost completely blunted $20 \mathrm{~min}$ after

TABLE I Systemic systolic pressure (SP) and heart rate (HR) responses to phenylephrine and nitroglycerin before and after hexamethonium $\left(20 \mathrm{mg} \cdot \mathrm{kg}^{-1}\right)$

\begin{tabular}{llllll}
\hline & \multicolumn{2}{c}{ Before hexamethonium } & & \multicolumn{2}{l}{ After hexamethonium } \\
\cline { 2 - 3 } \cline { 5 - 6 } \cline { 5 - 6 } & $\Delta S P(m m H g)$ & $\Delta H R\left(\right.$ beats $\left.\cdot \min ^{-1}\right)$ & & $\Delta S P(m m H g)$ & $\Delta H R\left(\right.$ beats $\left.\cdot \mathrm{min}^{-1}\right)$ \\
\hline Phenylephrinc $5 \mu \mathrm{g} \cdot \mathrm{kg}^{-1} \mathrm{IV}$ & $+32 \pm 13$ & $-17 \pm 9$ & $+33 \pm 13$ & $0 \pm 3^{*}$ \\
Nitroglycerin $10 \mu \mathrm{g} \cdot \mathrm{kg}^{-1} \mathrm{IV}$ & $-52 \pm 25$ & $+27 \pm 14$ & & $-47 \pm 11$ & $+1 \pm 1^{*}$ \\
\hline
\end{tabular}

Values represent mean \pm SD of maximal change.

$* P<0.01$ when compared with the corresponding values before hexamethonium. 
TABLE II Effects of $\mathrm{N}_{2} \mathrm{O}$ on haemodynamic variables during high-dose fentanyl anaesthesia in dogs without (Group I) and with hexamethonium (Group 2)

\begin{tabular}{|c|c|c|c|c|c|c|c|}
\hline \multirow[b]{2}{*}{ Variables } & \multirow[b]{2}{*}{ Group } & \multirow{2}{*}{$\begin{array}{l}\text { Baseline } \\
\text { (after } 100 \mu \mathrm{\mu g} \cdot \mathrm{kg}^{-1} \\
\text { fentanyl) }\end{array}$} & \multicolumn{4}{|c|}{$70 \% \mathrm{~N}_{2} \mathrm{O}$ plus $30 \% \mathrm{O}_{2}$} & \multirow{2}{*}{$\begin{array}{l}15 \min \\
\text { after } 100 \% \\
\mathrm{O}_{2}\end{array}$} \\
\hline & & & $15 \mathrm{~min}$ & $30 \mathrm{~min}$ & $45 \mathrm{~min}$ & $60 \mathrm{~min}$ & \\
\hline $\begin{array}{l}\mathrm{CO} \\
\left(\mathrm{L} \cdot \mathrm{min}^{-1}\right)\end{array}$ & $\begin{array}{l}1 \\
2\end{array}$ & $\begin{array}{l}1.52 \pm 0.27 \\
1.50 \pm 0.32\end{array}$ & $\begin{array}{l}1.33 \pm 0.21 \dagger \\
1.21 \pm 0.25 \dagger\end{array}$ & $\begin{array}{l}1.41 \pm 0.29 * \\
1.11 \pm 0.23 \dagger\end{array}$ & $\begin{array}{l}1.37 \pm 0.25 * \\
1.11 \pm 0.21 \dagger\end{array}$ & $\begin{array}{l}1.36 \pm 0.23^{*} \dagger \\
1.09 \pm 0.19 \dagger\end{array}$ & $\begin{array}{l}1.46 \pm 0.25^{*} \\
1.22 \pm 0.16^{*}\end{array}$ \\
\hline $\begin{array}{l}\mathrm{LV} \mathrm{dP/dt} \\
\quad\left(\mathrm{mmHg} \cdot \mathrm{sec}^{-1}\right)\end{array}$ & $\begin{array}{l}1 \\
2\end{array}$ & $\begin{array}{l}1522 \pm 161 \\
1555 \pm 164\end{array}$ & $\begin{array}{l}1300 \pm 94 \dagger \\
1255 \pm 170 \dagger\end{array}$ & $\begin{array}{l}1311 \pm 136 \dagger \\
1200 \pm 176 \dagger\end{array}$ & $\begin{array}{l}1333 \pm 205 \dagger \\
1188 \pm 159 \dagger\end{array}$ & $\begin{array}{l}1355 \pm 164 * \dagger \\
1144 \pm 149 \dagger\end{array}$ & $\begin{array}{l}1544 \pm 189 \ddagger \\
1400 \pm 156 \dagger \ddagger\end{array}$ \\
\hline $\begin{array}{l}\text { HR } \\
\quad \text { (beats } \cdot \min ^{-1} \text { ) }\end{array}$ & $\begin{array}{l}1 \\
2\end{array}$ & $\begin{array}{c}88 \pm 13 * \\
110 \pm 20\end{array}$ & $\begin{array}{r}97 \pm 15 \\
114 \pm 24\end{array}$ & $\begin{array}{r}98 \pm 16 \\
114 \pm 24\end{array}$ & $\begin{array}{l}100 \pm 15 \dagger \\
112 \pm 22\end{array}$ & $\begin{aligned} 99 & \pm 18 t \\
112 & \pm 23\end{aligned}$ & $\begin{array}{r}91 \pm 16 \ddagger \\
108 \pm 20 \ddagger\end{array}$ \\
\hline $\begin{array}{l}\text { MAP } \\
\quad(\mathrm{mmHg})\end{array}$ & $\begin{array}{l}1 \\
2\end{array}$ & $\begin{array}{l}87 \pm 9 \\
95 \pm 4\end{array}$ & $\begin{array}{l}92 \pm 10 \\
98 \pm 16\end{array}$ & $\begin{array}{l}95 \pm 11 \\
98 \pm 17\end{array}$ & $\begin{array}{l}97 \pm 10 \dagger \\
99 \pm 14\end{array}$ & $\begin{array}{c}100 \pm 11 \dagger \\
97 \pm 13\end{array}$ & $\begin{array}{l}102 \pm 11 \dagger \\
107 \pm 13\end{array}$ \\
\hline $\begin{array}{l}\text { SVR } \\
\quad\left(\text { dynes } \cdot \mathrm{sec} \cdot \mathrm{cm}^{-5} \text { ) }\right.\end{array}$ & $\begin{array}{l}1 \\
2\end{array}$ & $\begin{array}{l}4296 \pm 601 \\
4928 \pm 1150\end{array}$ & $\begin{array}{l}5210 \pm 935 \dagger \\
6441 \pm 2135 \dagger\end{array}$ & $\begin{array}{l}5210 \pm 1240^{\dagger} \\
7046 \pm 2406^{\dagger}\end{array}$ & $\begin{array}{l}5465 \pm 1185 \dagger \\
7090 \pm 2231 \dagger\end{array}$ & $\begin{array}{l}5697 \pm 1375 \dagger \\
6924 \pm 1939 \dagger\end{array}$ & $\begin{array}{l}5421 \pm 1227 \dagger \\
6699 \pm 1430 \dagger\end{array}$ \\
\hline $\begin{array}{l}\text { MPAP } \\
\qquad(\mathrm{mmHg})\end{array}$ & $\begin{array}{l}1 \\
2\end{array}$ & $\begin{array}{l}16 \pm 3 \\
16 \pm 5\end{array}$ & $\begin{array}{l}16 \pm 3 \\
16 \pm 4\end{array}$ & $\begin{array}{l}16 \pm 3 \\
16 \pm 4\end{array}$ & $\begin{array}{l}16 \pm 2 \\
16 \pm 4\end{array}$ & $\begin{array}{l}17 \pm 3 \\
16 \pm 4\end{array}$ & $\begin{array}{l}15 \pm 3 \\
15 \pm 3\end{array}$ \\
\hline $\begin{array}{l}\text { LVEDP } \\
\qquad(\mathrm{mmHg})\end{array}$ & $\begin{array}{l}1 \\
2\end{array}$ & $\begin{array}{l}12 \pm 2 \\
10 \pm 3\end{array}$ & $\begin{array}{l}12 \pm 3 \\
10 \pm 2\end{array}$ & $\begin{array}{l}12 \pm 3 \\
10 \pm 2\end{array}$ & $\begin{array}{l}11 \pm 2 \\
10 \pm 2\end{array}$ & $\begin{array}{l}11 \pm 3 \\
10 \pm 2\end{array}$ & $\begin{array}{r}11 \pm 3 \\
9 \pm 2\end{array}$ \\
\hline $\begin{array}{l}\text { PVR } \\
\quad\left(\text { dynes } \cdot \mathrm{sec} \cdot \mathrm{cm}^{-5}\right)\end{array}$ & $\begin{array}{l}1 \\
2\end{array}$ & $\begin{array}{l}198 \pm 80 \\
307 \pm 149\end{array}$ & $\begin{array}{l}222 \pm 100^{*} \\
420 \pm 125 \dagger\end{array}$ & $\begin{array}{l}229 \pm 105^{*} \\
467 \pm 204 \dagger\end{array}$ & $\begin{array}{l}286 \pm 100 * \dagger \\
454 \pm 181 \dagger\end{array}$ & $\begin{array}{l}309 \pm 112 \dagger \\
424 \pm 150 \dagger\end{array}$ & $\begin{array}{l}216 \pm 68 * \ddagger \\
390 \pm 92\end{array}$ \\
\hline $\begin{array}{l}\text { CVP } \\
\quad(\mathrm{mmHg})\end{array}$ & $\begin{array}{l}1 \\
2\end{array}$ & $\begin{array}{l}7 \pm 2 \\
6 \pm 1\end{array}$ & $\begin{array}{l}7 \pm 1 \\
6 \pm 2\end{array}$ & $\begin{array}{l}7 \pm 1 \\
6 \pm 2\end{array}$ & $\begin{array}{l}6 \pm 1 \\
6 \pm 2\end{array}$ & $\begin{array}{l}7 \pm 2 \\
6 \pm 2\end{array}$ & $\begin{array}{l}6 \pm 1 \\
7 \pm 1\end{array}$ \\
\hline $\begin{array}{l}\text { LVSW } \\
(\mathrm{g} \cdot \mathrm{m})\end{array}$ & $\begin{array}{l}1 \\
2\end{array}$ & $\begin{array}{l}18.1 \pm 4.9 \\
16.4 \pm 4.3\end{array}$ & $\begin{array}{l}14.9 \pm 2.7 \dagger \\
12.7 \pm 2.8 \dagger\end{array}$ & $\begin{array}{l}16.2 \pm 4.1^{* \dagger} \\
11.8 \pm 2.5 \dagger\end{array}$ & $\begin{array}{l}16.2 \pm 3.7^{* \dagger} \dagger \\
12.1 \pm 2.6 \dagger\end{array}$ & $\begin{array}{l}17.0 \pm 4.2^{*} \\
11.9 \pm 3.2^{\prime}\end{array}$ & $\begin{array}{l}20.3 \pm 5.0^{*} \ddagger \\
15.3 \pm 3.1 \ddagger\end{array}$ \\
\hline $\begin{array}{l}\text { RVSW } \\
(\mathrm{g} \cdot \mathrm{m})\end{array}$ & $\begin{array}{l}1 \\
2\end{array}$ & $\begin{array}{l}2.0 \pm 0.8 \\
1.7 \pm 0.9\end{array}$ & $\begin{array}{l}1.7 \pm 0.6 \\
1.5 \pm 0.8\end{array}$ & $\begin{array}{l}1.8 \pm 0.7 \\
1.4 \pm 0.8 \dagger\end{array}$ & $\begin{array}{l}1.8 \pm 0.4 \\
1.3 \pm 0.6 \dagger\end{array}$ & $\begin{array}{l}1.8 \pm 0.5 \\
1.2 \pm 0.7 \dagger\end{array}$ & $\begin{array}{l}2.0 \pm 0.8 \\
1.3 \pm 0.6 \dagger\end{array}$ \\
\hline
\end{tabular}

Abbreviations: CO, cardiac output; $L V$ dP/dt, maximal rate of rise of left ventricular pressure; HR, heart rate; MAP, mean arterial pressure; SVR, systemic vascular resistance; MPAP, mean pulmonary arterial pressure; LVEDP, left ventricular end-diastolic pressure; PVR, pulmonary vascular resistance; CVP, central venous pressure; LVSW, left ventricular stroke work; RVSW, right ventricular stroke work.

Values represent means $\pm \operatorname{SD}(n=9)$.

$* P<0.05$ compared between the two groups.

$\dagger P<0.05$ compared with baseline value in each group.

$\ddagger P<0.05$ compared with the value $60 \mathrm{~min}$ after $\mathrm{N}_{2} \mathrm{O}$.

treatment with hexamethonium $20 \mathrm{mg} \cdot \mathrm{kg}^{-1}$, whereas they reflected a normally functioning autonomic nervous system before hexamethonium (Table I).

The baseline $\mathrm{CO}$ and $\mathrm{LV} \mathrm{dP} / \mathrm{dt}$ after fentanyl 100 $\mu \mathrm{g} \cdot \mathrm{kg}^{-1}$ were similar in both groups (Table II). A significant decrease in $\mathrm{CO}$ was noted $15 \mathrm{~min}$ after $\mathrm{N}_{2} \mathrm{O}$ in each group. Sixty minutes after $\mathrm{N}_{2} \mathrm{O}, \mathrm{CO}$ decreased by 10 \pm 10 per cent and $27 \pm 8$ per cent of baseline values in Groups 1 and 2 , respectively $(P<0.05)$. Pure oxygen for $15 \mathrm{~min}$ allowed $\mathrm{CO}$ to recover partially in Group 2 . The decrease in $\mathrm{LV} \mathrm{dP} / \mathrm{dt}$ in Group 2 was greater than that in Group 160 min after $\mathrm{N}_{2} \mathrm{O}(27 \pm 7$ per cent vs $11 \pm 5$ per cent, $P<0.05$ ). Partial recovery of LV dP/dt was observed in both groups $15 \mathrm{~min}$ after 100 per cent oxygen (Table II).

The baseline MAP and SVR values were comparable in both groups, but the baseline HR was significantly greater in Group 2 than in Group 1 (Table II). The increases over baseline values in both HR and MAP were observed in Group 1 after $\mathrm{N}_{2} \mathrm{O}$, but not in Group 2. Systemic vascular resistance showed significant increases in both groups. However, no significant differences were found between the two groups in HR, MAP, and SVR at any point of measurements during $\mathrm{N}_{2} \mathrm{O}$ administration. Pulmonary vascular resistance increased significantly in both groups, although its magnitude was significantly greater in Group 2 than in Group 1 during $\mathrm{N}_{2} \mathrm{O}$ administration. Regarding the baseline values of LVSW and RVSW, no significant differences were observed between the two groups (Table II). The decreases of LVSW and RVSW in both groups during $\mathrm{N}_{2} \mathrm{O}$ administration were in the same direction and extent as those in $\mathrm{CO}$ or $\mathrm{LV} \mathrm{dP} / \mathrm{dt}$. However, $\mathrm{N}_{2} \mathrm{O}$ administration caused no significant differences between the two groups in RVSW. No significant changes in 
MPAP, LVEDP, and CVP were found throughout the experiment (Table II).

\section{Discussion}

The present results demonstrate that, during high-dose fentanyl anaesthesia in dogs, autonomic nervous system blockade by hexamethonium caused more pronounced $\mathrm{N}_{2} \mathrm{O}$-induced myocardial depression. Since cardiac vagal tone has a negative inotropic effect and its elimination with hexamethonium should enhance myocardial contractility, it must be assumed that the sympathetic ganglionic blocking effect of hexamethonium is responsible for this augmentation of $\mathrm{N}_{2} \mathrm{O}$-induced myocardial depression. Although the reasons why $\mathrm{N}_{2} \mathrm{O}$ should have such myocardial depressant effects in the presence of opioids are unknown, it has been suggested that opioids block centrally mediated sympathomimetic effects of $\mathrm{N}_{2} \mathrm{O}$, thus unmasking its direct depressant effects on the heart. ${ }^{13,14}$ However, our data indicate that even in the presence of opioids, the sympathetic nervous system, in some degree, compensates the $\mathrm{N}_{2} \mathrm{O}$-induced myocardial depression because it is less prominent in dogs without autonomic blockade than in dogs with autonomic blockade.

Hexamethonium was used to eliminate autonomic function because it blocks autonomic ganglionic neurotransmission. ${ }^{15}$ In spite of the highly active competition with acetylcholine at the ganglionic post-synaptic nicotinic receptor, hexamethonium lacks the other properties which often accompany a relationship to acetylcholine: it has almost no neuromuscular blocking action, no atropine-like action, no atropine-sensitive muscarine-like action. ${ }^{16}$ In our study, to determine whether the opioids block the central sympathetic outflow elicited by $\mathrm{N}_{2} \mathrm{O}$, hexamethonium met the requirements for the model that the increased central sympathetic outflow by $\mathrm{N}_{2} \mathrm{O}$ does not affect the peripheral postganglionic sympathetic tone. Blockade of parasympathetic ganglia, that is simultaneously induced by hexamethonium, has little effect on our conclusions for two reasons. First, the cardiac effect of vagal ganglionic blockade, aside from positive chronotropic and dromotropic effects, is to increase myocardial contractility through the elimination of negative inotropy of vagal tone, which would lead to reduction in the differences of myocardial depression between the two groups. Second, peripheral vascular tone has been shown to be controlled mainly by the sympathetic nervous system. ${ }^{17}$ The baroreflex responses to phenylephrine and nitroglycerin observed before hexamethonium in the pentobarbital anaesthetized dogs were almost completely eliminated by this compound (Table I), indicating that the autonomic nervous system was incapacitated in the presence of hexamethonium.
The changes of HR and SVR that can be assumed to reflect the responses of autonomic nervous system to $\mathrm{N}_{2} \mathrm{O}$ in the presence of opioids are conflicting in previous studies. The use of $\mathrm{N}_{2} \mathrm{O}$ during high-dose opioid anaesthesia has been shown to be associated with signs of sympathetic stimulation such as increased HR or SVR. ${ }^{2,4,11}$ In contrast, decreased HR or unchanged SVR has also been reported in the combined use of $\mathrm{N}_{2} \mathrm{O}$ and opioids. ${ }^{1,3,12}$ The present data showing that both $\mathrm{HR}$ and SVR increased in the dogs without hexamethonium seem to favour the sympathomimetic effects of $\mathrm{N}_{2} \mathrm{O}$ in the presence of opioids.

The MAP increased significantly in the dogs without hexamethonium during $\mathrm{N}_{2} \mathrm{O}$ application because of the significant increase in SVR. This increase in MAP is in contradiction to the previous reports showing the decreased, ${ }^{1,3,11,12}$ or unchanged ${ }^{2,4}$ SAP during opioid and $\mathrm{N}_{2} \mathrm{O}$ anaesthesia. The cause of this discrepancy is not known, but is possibly related to species differences in the SVR response to $\mathrm{N}_{2} \mathrm{O}$. On the other hand, in the hexamethonium-treated dogs the significant increase of SVR resulted in a slight but not significant increase of MAP because of the more pronounced myocardial depression in this group of dogs. These increases in MAP and SVR, however, should not be considered as the centrally mediated compensatory response of sympathetic nervous system because autonomic ganglionic blockade had been induced. These findings, that SVR increased irrespective of autonomic ganglionic blockade, might support the possibility that $\mathrm{N}_{2} \mathrm{O}$ has a direct vasoconstricting effect or causes a release of catecholamines from postganglionic nerve terminals as suggested by Eisele et al. ${ }^{6}$

It has been suggested that isolated left ventricular depression results from the addition of $\mathrm{N}_{2} \mathrm{O}$ to morphine anaesthesia but without right ventricular impairment. ${ }^{18}$ This is in agreement with our findings as RVSW showed no significant changes although LVSW significantly decreased during $\mathrm{N}_{2} \mathrm{O}$ application in the dogs without hexamethonium (Table II).

It is difficult to define what doses of fentanyl are required to obtain the same level of anaesthesia in dogs as that of high-dose fentanyl anaesthesia in humans. However, the dose of $100 \mu \mathrm{g} \cdot \mathrm{kg}^{-1}$ of fentanyl in this study seemed to be adequate since Arndt et al. reported that the maximum effect of fentanyl was observed in the dog at plasma concentrations around $30 \mathrm{ng} \cdot \mathrm{ml}^{-1}$, which was achieved by a cumulative dose of $67.5 \mu \mathrm{g} \cdot \mathrm{kg}^{-1}{ }^{19} \mathrm{~A}$ possible criticism of our study could be the use of pentobarbital as a basal anaesthetic agent, although any anaesthetic agent would have some effect on the results. However, this effect can be regarded as standardized since the total doses of pentobarbital administered and 
baseline values reflecting myocardial contractility such as $\mathrm{CO}$ or $\mathrm{LV} \mathrm{dP} / \mathrm{dt}$ are similar and comparable between the two groups (Table II).

Patients with impaired left ventricular function, who already have increased sympathetic tone and thus have an exhausted sympathetic reserve, are known to be more susceptible to the myocardial depressant effect of $\mathrm{N}_{2} \mathrm{O} \cdot{ }^{20}$ This is compatible with our findings that $\mathrm{N}_{2} \mathrm{O}$ caused profound myocardial depression in the absence of functioning sympathetic tone (Table II). Therefore it is likely that preanaesthetic sympathetic tone as well as the extent of myocardial impairment is a primary determinant of myocardial depression caused by the combined use of fentanyl and $\mathrm{N}_{2} \mathrm{O}$.

In summary, elimination of sympathetic tone with hexamethonium aggravated the myocardial depression induced by $\mathrm{N}_{2} \mathrm{O}$ during high-dose fentanyl anaesthesia. The signs of augmented sympathetic tone such as the increase of HR or SVR in dogs with intact sympathetic tone provide further evidence that the sympathetic nervous system exerts compensatory effects upon $\mathrm{N}_{2} \mathrm{O}$ induced myocardial depression in the presence of opioids. Therefore intact sympathetic tone seems to be essential to prevent the profound myocardial depression when $\mathrm{N}_{2} \mathrm{O}$ is given during high-dose fentanyl anaesthesia. In the clinical setting these data suggest that patients with minimal sympathetic reserve are more susceptible to the myocardial depressant effect of $\mathrm{N}_{2} \mathrm{O}$ when it is given in combination with fentanyl.

\section{References}

1 Stoelting RK, Gibbs PS, Creasser CW, Peterson

$C$. Hemodynamic and ventilatory responses to fentanyl, fentanyl-droperidol, and nitrous oxide in patients with acquired valvular heart disease. Anesthesiology $1975 ; 42: 319-24$.

2 Lunn JK, Stanley TH, Eisele J, Webster L, Woodward $A$. High dose fentanyl anesthesia for coronary artery surgery: plasma fentanyl concentrations and influence of nitrous oxide on cardiovascular responses. Anesth Analg 1979; 58: 390-5.

3 Meretoja OA, Takkunen $O$, Heikkilae $H$, Wegelius $U$. Hemodynamic response to nitrous oxide during high-dose fentanyl pancuronium anesthesia. Acta Anaesthesiol Scand 1985; 29: 137-41.

4 Balasaraswathi K, Kumar P, Rao TLK, El-Etr AA. Left ventricular end-diastolic pressure (LVEDP) as an index for nitrous oxide use during coronary artery surgery. Anesthesiology 1981; 55: 708-9.

5 Motomura S, Kissin I, Aultman DF, Reves JG. Effects of fentanyl and nitrous oxide on contractility of blood- perfused papillary muscle of the dog. Anesth Analg 1984; 63: 47-50

6 Eisele JH, Smith NT. Cardiovascular effects of 40 percent nitrous oxide in man. Anesth Analg 1972; 51: 956-63.

7 Fukunaga AF, Epstein RM. Sympathetic excitation during nitrous oxide-halothane anesthesia in the cat. Anesthesiology 1973; 39: 23-36.

8 Smith NT, Eger EI II, Stoelting RK, Whayne TF, Cullen D, Kadis $L B$. The cardiovascular and sympathomimetic responses to the addition of nitrous oxide to halothane in man. Anesthesiology 1970; 32: 410-21.

9 Smith NT, Calverley RK, Prys-Roberts C, Eger EI II, Jones $C W$. Impact of nitrous oxide on the circulation during enflurane anesthesia in man. Anesthesiology 1978; 48: 345-9.

10 Dolan WM, Stevens WC, Eger EI II et al. The cardiovascular and respiratory effects of isoflurane-nitrous oxide anaesthesia. Can Anaesth Soc J 1974; 21: 557-68.

11 McDermott $R W$, Stanley $T H$. The cardiovascular effects of low concentrations of nitrous oxide during morphine anesthesia. Anesthesiology 1974; 41: 89-91.

12 Stoelting RK, Gibbs PS. Hemodynamic effects of morphine and morphine-nitrous oxide in valvular heart disease and coronary-artery disease. Anesthesiology 1973; 38: 45-52.

13 Flaim $S F$, Zelis $R$, Eisele $J H$. Differential effects of morphine on forearm blood flow: attenuation of sympathetic control of the cutaneous circulation. Clin Pharmacol Ther 1978; 23: 542-6.

14 Stoelting RK. Pharmacology and Physiology in Anesthetic Practice. 1st ed. Philadelphia: J.B. Lippincott, 1987 49.

15 Gurney AM, Rang HP. The channel-blocking action of methonium compounds on rat submandibular ganglion cells. Br J Pharmacol 1984; 82: 623-42.

16 Paton WDM, Zaimis EJ. The methonium compounds. Pharmacol Rev 1952; 4: 219-53.

17 Mellander S, Johansson B. Control of resistance, exchange, and capacitance functions in the peripheral circulation. Pharmacol Rev 1968; 20: 117-96.

18 Lappas DG, Buckley $M J$, Laver MB, Daggett WM, Lowenstein $E$. Left ventricular performance and pulmonary circulation following addition of nitrous oxide to morphine during coronary-artery surgery. Anesthesiology $1975 ; 43: 61-9$.

19 Arndt JO, Mikat M, Parasher C. Fentanyl's analgesic, respiratory, and cardiovascular actions in relation to dose and plasma concentration in unanesthetized dogs. Anesthesiology 1984; 61: 355-61.

20 Eisele JH, Reitan JA, Massumi RA, Zelis RF, Miller $R R$. Myocardial performance and $\mathrm{N}_{2} \mathrm{O}$ analgesia in coronary-artery disease. Anesthesiology 1976; 44: 16-20. 